DOI https://doi.org/10.30525/978-9934-26-182-4-24

\title{
ФЕНОМЕН ПРОКРАСТИНАЦІЇ У ЛІКАРІВ-ІНТЕРНІВ ЗА ФАХОМ «ОТОРИНОЛАРИНГОЛОГІЯ»
}

\author{
Схалов В. В. \\ кандидат медичних наук, дочент, \\ доиент кафедри анестезіології, інтенсивної терапії \\ та медицини невідкладних станів \\ факультету післядипломної освіти \\ Дніпровський державний медичний університет \\ Хоботова Н. В. \\ кандидат медичних наук, доцент, \\ доиент кафедри оториноларингології \\ Дніпровський державний медичний університет \\ Станін Д. М. \\ кандидат медичних наук, дочент, \\ дочент кафедри анестезіології, інтенсивної терапії \\ та медицини невідкладних станів \\ факультету післядипломної освіти \\ Дніпровський державний медичний університет \\ м. Дніпро, Украӥна
}

Феномен, який позначається терміном "прокрастинація", останнім часом завоював величезний інтерес $з$ боку громадськості, та привертає дедалі все більше уваги дослідників та психологів у всьому світі. У наших попередніх дослідженнях було визначено що 43,2\% респондентів не вважають доцільним взагалі виконувати певні завдання, якщо це їм нічим не загрожує. За власною оцінкою прокрастинаторами вважають себе 69,5\% лікарів-інтернів [1, с. 76; 2, с. 308].

Нами було проведене анонімне анкетування більше 300 лікарівінтернів різних спеціальностей після звершення циклу "Невідкладні стани". Були використана шкала загальної прокрастинації К. Лей в адаптації Т.Ю. Юдєєвої (2011) та іiї причин М.С. Дворник (2018) [3, с.107-112]. Попередні результати показали, що середній рівень зволікання в усіх групах дослідження дорівнював 62,25 - 63,5 балів, що відповідало середньому рівню схильності до прокрастинації та не мало фахової достовірної різниці $(\mathrm{p}=1)$. Частка респондентів з високим рівнем прокрастинації склала у інтернів 1-го року навчання $21,25 \%$. Однак, ми не могли задовольнитися такими результатами та провели повторне 
анкетування за створеним на засадах теоретичного аналізу проблеми походження відтермінування опитувальником М.С. Дворник (2018), провідною характеристикою якого стало припущення про те, що час від часу будь-яка особистість може демонструвати ознаки прокрастинації $[3$, с. 59-60]. Завдяки отриманим результатам ми провели порівняльний аналіз причин особистісної схильності до відтермінування вирішення завдань у лікарів-інтернів за фахом "Оториноларингологія" та середніми показниками молодих колег різних спеціальностей.

Як було вказано вище, переважна частка всіх опитаних характеризувалася середнім рівнем схильності до прокрастинації. Але в загальній масі лікарів-інтернів високий рівень зволікання показали 43,3\% респондентів за складовою "орієнтація на соціальну винагороду". Друге місце $(29,5 \%)$ посіла "недооцінка готовності до виконання завдання". Низьку схильність до прокрастинації показали $16,3 \%$ респондентів за пунктом "зниження рівня зацікавленості".

Таблиця 1

\begin{tabular}{|c|c|c|c|c|c|c|}
\hline \multirow{2}{*}{$\begin{array}{c}\text { Причини } \\
\text { особистісної } \\
\text { схильності до } \\
\text { відтермінува- } \\
\text { ння завдань }\end{array}$} & \multicolumn{2}{|c|}{ Низьй } & \multicolumn{2}{|c|}{ Середній } & \multicolumn{2}{|c|}{ Високий } \\
\cline { 2 - 7 } & $\begin{array}{c}\text { Ліку- } \\
\text { вальна } \\
\text { справа }\end{array}$ & ЛОР & $\begin{array}{c}\text { Ліку- } \\
\text { вальна } \\
\text { справа }\end{array}$ & ЛОР & $\begin{array}{c}\text { Ліку- } \\
\text { вальна } \\
\text { справа }\end{array}$ \\
\hline $\begin{array}{c}\text { Недооцінка } \\
\text { готовності до } \\
\begin{array}{c}\text { виконання } \\
\text { завдання }\end{array}\end{array}$ & $0 \%$ & $6,4 \%$ & $51,2 \%$ & $64,1 \%$ & $48,8 \%$ & $29,5 \%$ \\
\hline $\begin{array}{c}\text { Подолання } \\
\text { страху } \\
\text { відповідальності }\end{array}$ & $0 \%$ & $8,6 \%$ & $89,8 \%$ & $81,3 \%$ & $10,2 \%$ & $10,1 \%$ \\
\hline $\begin{array}{c}\text { Знижений рівень } \\
\text { зацікавленості }\end{array}$ & $19,1 \%$ & $16,3 \%$ & $59,8 \%$ & $74,0 \%$ & $21.1 \%$ & $9,7 \%$ \\
\hline $\begin{array}{c}\text { Орієнтація на } \\
\text { соціальну } \\
\text { винагороду }\end{array}$ & 0 & $3,4 \%$ & $30,3 \%$ & $53,3 \%$ & $68,7 \%$ & $43,3 \%$ \\
\hline $\begin{array}{c}\text { Схильність до } \\
\text { педантизму }\end{array}$ & $10,1 \%$ & $4,1 \%$ & $89,9 \%$ & $88,5 \%$ & $0 \%$ & $7,4 \%$ \\
\hline
\end{tabular}


При порівняльному аналізі причин прокрастинації у лікарів-інтернів за фахом "Оториноларингологія" та молодих колег різних спеціальностей лікувального профілю було визначено, що при повній відсутності респондентів 3 низьким рівнем схильності, частка колег 3 високим показником перевищує на $39,5 \%$ середній показник інтернського середовища. Це може бути інтерпретоване як висока схильність суб'єктів навчання до відтермінування через оцінювання завдань як складних, тривалих, неважливих через особистісну нестабільність, недостатність підтримки або контролю, недооцінку часу та власних ресурсів на виконання роботи [3, с. 62].

Низького рівня схильності за складовою "подолання страху відповідальності" не було зареєстровано в жодного оториноларинголога супроти 8,6\% загальної вибірки. Інші ступені притаманності статистично не відрізнялися від інтернів різних фахів. Це свідчить про тривожну поведінку уникання важливих, складних, незнайомих завдань, пошук особливих умов для їх виконання. Це певна фобія прийняття рішень, своєрідний захист від психічного i фізичного перенавантаження $[3$, с. $63-64 ; 4$, с. 12$]$.

В літературі описано варіант захисту, який набув назву "Jonah complex". 3 причини «страху досягнень» більше половини людей у світі навіть не звертаються до завдання і не шукають дійсних шляхів реалізації внутрішнього потенціалу. Страх невдачі (або успіху) безпосередньо передбачає ситуацію оцінювання. Події з неминучою оцінкою діяльності зазвичай призводять до підвищення переживання реальної або уявної небезпеки. Молодий колега, подумки припускаючи можливість не впоратися із завданням, не хоче розчарувати себе або інших. Рефлексія та зворотний зв'язок при цьому негативно впливають на рівень самооцінки, який потрібен особистості для звичного функціонування. Побоювання невдачі може свідчити про реальний або уявний брак здібностей. Недооцінка власних можливостей спричиняє почуття неспроможності та безпорадності. Підсвідомо суб'єкт навчання обирає прокрастинацію замість самовдосконалення. Страх перед успіхом може поєднуватися 3 небажанням людини стати центром загальної уваги, учасником конкурентної боротьби, викликати в когось заздрість або роздратування, зайняти нетипову для своєї соціальної групи позицію, неготовністю взяти на себе відповідальність [2, с. 62].

Що стосується "зниження рівня зацікавленості", то у інтернівоториноларингологів виникає певне протиріччя: з одного боку 19,1\% респондентів показали низку схильність до цієї причини прокрастинації, в той же час 21,1\% 3 них у значній мірі притаманна байдужість. Обидва 
показники значно перевищують такі у загальній вибірці. Високі показники тут демонструють їхню загальну незацікавленість щодо справ, які потрібно виконати. Наші інтерни показали високу орієнтацію на соціальну винагороду, висока схильність до чого на $38 \%$ перевищує середній показник інших респондентів. Досліджувані з високими показниками за цим фактором виступають проти неприйнятних умов спілкування, виявляляють бажання співпрацювати з певними людьми, спрямовані на соціальне прийняття [2, с. 60]. Демократизація сучасного інтернського середовища полягає в складності 3 високою самооцінкою, 3 відстоюванням невід’ємного права на особистий суверенітет, у відчутті більшої свободи і більшої гнучкості, ніж у старших поколінь. У наших попередніх дослідженнях найвищу самооцінку продемонстрували 93,5\% всіх опитаних [4, с. 12].

Педантичні схильності пов'язують природу відтермінування 3 характерологічною потребою виваженості, правильності, послідовності. Тому високі показники за цим фактором свідчать про те, що респонденти відкладають свої справи через особистісну нерішучість, неквапливість, розміреність [2, с. 59]. Схильність до педантизму інтернам досліджуваної групи була менш притаманна, ніж в загальному інтернському середовищі, що свідчить про більшу психофункціональну мобільність, значні адаптивні можливості, можливо, більшу схильність до прекрастинації.

Взагалі більшість людей, які мають схильність (особливо хронічну) до прокрастинації, сприймають цей феномен як негативне явище, яке заважає їм плідно жити та працювати. Більше 80\% 3 них прагнуть позбутися такої залежності шляхом відвідування тренінгів, праці з психотерапевтом тощо.

Таким чином, лікарі-інтерни за фахом "Оториноларингологія" показали значно більш високі показники з браку готовності до виконання завдання, ніж молоді колеги інших спеціальностей, але значно нижчий рівень схильності до педантизму. Відкритим залишається питання про позитивний та негативний ефект прокрастинації. 3 кожним днем дедалі більше дослідників схиляються до позитивного впливу цього феномена. Відкладання справ є нормою, доки не починають виникати серйозні проблеми, а хронічна прокрастинація $\epsilon$ ознакою психічного розладу [5, с. 168]. Прокрастинація не є суто негативною якістю особистості, якщо вона не усвідомлюється як адитивна звичка і не завжди така страшна, як хтось, можливо, її собі уявляє.

\section{Лiтература:}

1. Ekhalov V.V., Kravets O.V., Stus V.P., Moiseenko M.M., Barannik S.I. Sociopsychological image of the modern intern (educational and social 
research). Урологія. 2021. т. 25. № 1. Р. 71-80. doi: 10.26641/23075279.25.1.2021.231404

2. Yekhalov V.V., Kravets O.V., Krishtafor D. A. Psychological Features of the Modern Intern. The world of science and innovation. Abstracts of the 6th International scientific and practical conference. Cognum Publishing House. London, United Kingdom. 2021. P. 304-311.

3. Дворник М. С. Прокрастинація в конструюванні особистісного майбутнього: монографія. Кропивницький : Імекс-ЛТД. 2018. 120 с.

4. Yekhalov V. V., Gorbuntsov V.V. Psychological features of a modern intern dinamic observation. Bioenergetics in Medicine and Biology. 2021. V. 1(6). P. 1-20. doi: 10.26886/2523-6938.1(6)2021.1.

5. Колесникова В.И., Денисенко Ю. С. Теоретический анализ феномена прокрастинации в парадигме глубинной психологии. Психология и педагогика в Крыму: пути развития. 2020. № 2. С. 155-172.

DOI https://doi.org/10.30525/978-9934-26-182-4-25

\title{
АНОСМІЯ ТА ПАРОСМІЯ У ПОСТКОВІДНИЙ ПЕРІОД. ОСОБЛИВОСТІ ЗМІН НЮХУ
}

\author{
Коломійченко Ю. В.
}

студентка 3 курсу медичного факультету

Одеський національний медичний університет

\author{
Кузьменко I. A. \\ кандидат медичних наук, \\ дочент кафедри Загальної та клінічної патологічної фізіології \\ імені В. В. Підвисочького \\ Одеський національний медичний університет \\ м. Одеса, Україна
}

Аносмія та паросмія - найбільш розповсюджені симптоми прояву класичного SARS-CoV-2 та інших штамів на ранніх етапах інфікування, але не $\epsilon$ маркерними симптомами, оскільки ці порушення нюху можуть виникати при синуситах, респіраторних інфекціях, черепно-мозкових травмах i т.д.. Вони тимчасові та можуть бути короткочасними або довготривалими. Аносмія дуже часто супроводжується адгезією. В постковідний період для оцінки рівня пошкодження нюху, 